\title{
Muslims Should Pay More Attention to Human Relations
}

\author{
Daud Batchelor*
}

The contemporary situation in much of the Muslim world suggests to us that, while teachings on ibadat (ritual worship, including prayer, fasting, zakat, hajj) have been faithfully conveyed to many of us by our Imams, instruction in the other category of Islamic law, mu'amalat (civil transactions and social interactions), has generally been given less attention. This has led to shortcomings in the Muslim world, especially in the context of our duty to provide an exemplary moral example for the rest of humanity.

Mu'amalat focuses on the relationship between people (hablum minannass), rather than between man and his Creator (hablum minAllah). In rather broad terms, it can be considered as encompassing the fields of Islamic banking, finance and economics, national governance, and the justice system. It can even be said to include good manners $(a d a b)$. Indications that Muslim countries are lagging behind in these fields come from Scheherazade Rehman and Hossein Askari's publication, "How Islamic are Islamic Countries?" In this article, the authors rated 208 Muslim and non-Muslims countries based on their perceived adherence to Qur'anic teachings and the Sunnah of the Prophet Muhammad (peace be upon him). In the societal fields mentioned above, they found that New Zealand was best overall, with a total of 37 other non-Muslim countries scoring better than the top-rated Muslim country, Malaysia. My own research on this subject, published as "A New Islamic Index of Wellbeing for Rating Muslim Countries," found that the Muslim world fared worse than the global average for Islamically-significant social interaction indicators such as adult literacy, female secondary school attendance, maternal and infant mortality rates, and corruption. My research further showed that those Muslim countries which did best in traditional ibadah indicators - mainly West African countries and Afghanistan - displayed poor social interactions. It deserves further study to demonstrate whether this is due to the mistaken view that outward signs of piety (like regular prayer and fasting) are of more consequence than factors like good dealings with fellow Muslims, concern for weaker societal members (women, infants, the poor), and so on. Certainly, this possibility is suggested by Transparency International's 2015 Corruption Perceptions Index, which showed that ten of the world's 15 most corrupt countries are Muslim. Such is against the Prophet's (pbuh) clear teaching that "cursed is the one who bribes and the one who takes a bribe" (Abu Daud \#1595).

Although ibadah actions are unlikely to change over time, mu'amalat laws are more susceptible to the influence of socio-cultural and even technological change. 
They therefore need the application of fresh ijtihad (independent reasoning) from time to time, to ensure that the law continues to promote justice and social equity. In recent history, however, the reform of mu'amalat law has not kept pace with societal developments, resulting in some anachronisms. These include, for example, the continued division of the world into dar ul-Islam (abode of Islam) and dar ul-harb (abode of war) and despite the fact that today non-Muslim countries have peaceful relations with Muslim countries, making the term dar ul'ahd (abode of treaty) more appropriate. Moreover, in many formerly-colonised Muslim countries, the application of shari 'ah is often restricted to personal and family law, while other issues are governed by western codes. This has caused ijtihad to fall by the wayside, since the legal fields to which it was most commonly applied have been appropriated by colonial-era legal structures, leaving Muslim jurists without a role to ensure that mu'amalat laws keep pace with contemporary developments.

But alhamdulillah, today there is much progress in the field of mu'amalat, especially with the rapid and worldwide expansion of Islamic finance and the halal industry, in addition to improvements in the status of women. What is further required, however, is a strengthening and sustaining of relations between Muslims and non-Muslims, especially those who are fellow citizens and neighbours. The Prophet (pbuh) said, "He is not a believer until his neighbour is safe from injurious behaviour on his part" (Tirmidhi \#1292). Allah the Most High in Sura al-Nisa, verse 36, also ordered believers to do good to kinsfolk, orphans, those in need, close neighbours (including those who are strangers), and wayfarers. Indeed, Muslim kindness to the wayfarer was a prime reason behind this author's conversion to Islam: while receiving superb hospitality as a nonMuslim travelling through Indonesia in the 1970s, I eventually accepted Islam as the Truth from the Almighty. Muslims need to recapture this generous spirit focused on the welfare of others.

\section{Notes}

* Daud Batchelor is former Research Fellow at IAIS Malaysia (Email: daud. batchelor@gmail.com). 